\title{
STILISTIKA MORFOLOGI AL-QURAN JUZ 30
}

\section{Aunul Hakim}

\author{
Email: aunulhakim@gmail.com
}

Fakultas Humaniora dan Budaya Universitas Islam Negeri Maulana Malik Ibrahim Malang Alamat Korepondensi: Jalan Gajayana 50 Malang, Telp/Fax (0341) 570872

\begin{abstract}
There are some aspects of al-Quran miracle, among other are the language and content. AlQuran is popularly known of using the popular vocabularies that are commonly used by the people but full up with meaning and decorated with beautiful language style. One of the characteristics is, in Juz 30 contains short verses, so that they can be read in a beautiful unity of style, and as consequence, it can be seen and felt harmonious in its rhythm and rhymes. Stylistics is a branch of language science that observes the language used in literary text, an interdisciplinary of linguistics and literature. There are found out the morphological stylistics in the Juz 30 in the form of one addition of morpheme in 'wazan', elimination of one morpheme in wazan, morpheme change in wazan, and change in word meaning. The morphemic addition in wazan is for example, addition of harf illat, tasydid, and ha' saktah, while the elimination one morpheme such as the elimination of harf illat, harf ta' mudlara'ah, ya' mutakallim, and alif isim fail. The change of wazan can be found in the wazan jamak, masdar, isim shifat, fiil and isim. The change of meaning covers the widening meaning of isim, fi'il and word.
\end{abstract}

\section{Kata Kunci}

Stilistika, Morfologi, Wazan

\section{Pendahuluan}

Al-Qur'an, selain isinya, bahasanya pun merupakan bagian dari mukjizat al-Qur'an yang menarik untuk dikaji. Dalam aspek bahasa, alQuran memiliki keindahan dan ketinggian nilai sastra yang belum, dan bahkan tidak akan terkalahkan oleh apapun dan siapa pun. Di dalam al-Quran juga terpadu keindahan bahasa, ketelitian, keseimbangan, kedalaman makna, kekayaan, dan kebenaran, serta kemudahan pemahaman dan kehebatan kesan yang ditimbulkannya. Bahkan, Nashr Hamid memandang al-Quran sebagai teks sastra Arab yang teragung dalam sejarah.

Beberapa studi tentang al-Quran telah banyak dilakukan, misalnya kajian tentang stilistika alQuran yang dilakukan oleh Qalyubi(1997), dan kajian linguistik-semantik terhadap al-Quran yang dilakukan oleh Audah (1995), serta konsep sastra dalam al-Quran yang diteliti oleh Saifuddin (2005). Kajian-kajian di atas lebih bersifat umum dalam mengkaji kaitan linguistik atau sastra dengan al-Quran. Kajian yang lebih spesifik dan terfokus pada unsur-unsur sastra atau linguistik, misalnya kajian tentang struktur morfologi, morfologi, semantik, dan fonologi al-Quran masih jarang.

Ada suatu pertanyaan yang sering diajukan pada para pengajar dan pembelajar bahasa Arab atau masyarakat umum, yakni mengapa bahasa alQuran cenderung lebih sulit untuk dipahami dibanding teks bahasa Arab lainnya sehingga memerlukan alat bantu tafsir atau terjemahan? Apa sesungguhnya yang membedakan teks alQuran dengan teks lain yang sama-sama berbahasa Arab?.Penulis berasumsi mungkin kesulitan ini muncul karena bentuk morfologi alQuran mempunyai keunikan atau kekhasan (style) tersendiri. Sementara itu, selama ini morfologi Arab hanya membahas kaidah-kaidah umum saja dan kalaupun dibahas, morfologi alQuran itu hanya diberikan dalam porsi yang kecil, yakni sebagai al-mustatsnayat (perkecualian dari kaidah umum).

\section{Pengertian dan Obyek Kajian Stilistika}

Stilistika secara sederhana dapat diartikan sebagai kajian linguistik yang obyeknya berupa style. Sedang style adalah cara penggunaan bahasa dari seseorang dalam konteks tertentu dan untuk tujuan tertentu (Lecce, 1984:10). 
Menurut Keraf (1984:112), kata style diturunkan dari kata lain stilus, yaitu semacam alat untuk menulis pada lempengan lilin. Keahlian menggunakan alat ini akan mempengaruhi jelastidaknya tulisan pada lempengan tadi. Ketika dititikberatkan pada keahlian menulis indah, maka istilah style lalu berubah menjadi kemampuan dan keahlian untuk menulis atau mempergunakan kata-kata secara indah. Dari kata tersebut muncul istilah linguistik "stilistika".

Dalam kamus linguistik disebutkan, stilistika adalah ilmu yang menyelidiki bahasa yang dipergunakan dalam karya sastra; ilmu interdisipliner antara lingustik dan kesusasteraan (Kridalaksana, 1983:157). Dalam literatur Arab, stilistika dikenal dengan istilah uslub.

Dari beberapa pengertian di atas tampak dua aspek yang mencolok dalam kajian stilistika, yaitu aspek estetika dan aspek linguistik. Aspek estetika berkaitan dengan ciri khas yang digunakan penutur bahasa atau penulis karya sastra. Aspek linguistik berkaitan dengan ciri khas penggunaan pola-pola gramatika, fonologi, dan semantik. Mungkin timbul pertanyaan dari mana stilistika memulai kajiannya, dari aspek estetika atau linguistik?

Stilistika mengkaji seluruh fenomena bahasa mulai dari fonologi hingga semantik (Ayyad, 1982:48). Agar ranah kajian tidak terlalu luas, kajian stilistika biasanya dibatasi pada suatu teks tertentu dengan memperhatikan preferensi penggunaan kata atau struktur bahasa, mengamati hubungan-hubungan pilihan itu untuk mengidentifikasi ciri-ciri stilistik seperti morfologi, leksikal, retoris atau deviasi (penyimpangan dari kaidah umum tatabahasa) (Sudjiman, 1993:14).

\section{Stilistika al-Quran}

Aspek-aspek bahasa yang dikaji dalam stilistika al-Quran sama seperti aspek-aspek stilistika yang lain, yaitu meliputi aspek fonologi, semantik, gramatika dan leksikologi. Sampai saat ini belum diketahui siapa peletak pertama ilmu stilistika alQuran. Sejak abad III Hijrah studi ini telah dilakukan, namun dalam nuansa ilmu balaghah, sebagaimana dilaksanakan oleh al-Rummani (296-386 H) dalam bukunya al-Nukat fi I'jaz alQuran, al-Khattabi dalam bukunya Bayan I'jaz alQuran. Mereka memasukkan bahasan ini ke dalam ranah kajian balaghah al-Quran.

Menurut Syihabuddin (2002:34), al-Zarqani dalam bukunya Manahil al-Irfan fi Ulum al-Quran telah memisahkan stilistika al-Quran dari balaghah al-Quran, dan menjadikannya sebagai ilmu tersendiri sebagai bagian dari ilmu-ilmu alQuran. Hanya saja penyusunannya belum mengikuti metode stilistika yang dikembangkan dewasa ini.

\section{Konsep Makna dan Analisis Makna Morfologi}

Al-Ashfahani mengemukakan bahwa kata ma'na berasal dari kata 'ana yang berarti "melahirkan". Karena itu makna diartikan sebagai sesuatu yang dilahirkan dari tuturan. Menurut Mujahid, telaah ihwal kata dan makna telah menjadi perhatian para ulama salaf (baca: klasik) jauh sebelum para ahli linguistik Barat memulainya. Para ahli yang membahas masalah itu dapat dibagi menjadi tiga kelompok: (1) ahli ushul fiqh, (2) para sastrawan, dan (3) ahli bahasa.

Ahli bahasa memandang bahasa sebagai gudang perbendaharaan yang perlu diungkapkan isinya, karena itu telaah mereka terhadap hubungan antara kata dan maknanya meliputi berbagai aspek, di antaranya tentang etimologi, sinonim, homonim, polisemi, antonim, makna denotatif dan konotatif, perubahan makna dan pengembangan kata.

Adapun pandangan sastrawan, dalam hal ini para ahli balaghah, menurut Hasan memfokuskan perhatiannya pada tiga aspek: (1) aspek struktur, (2) aspek makna, dan (3) aspek keindahan ungkapan(Syihabuddin, 2002:26). Ketiga Aspek ini dapat disajikan sebagai berikut.

Pertama, aspek struktur. Yang dimaksud struktur oleh ahli balaghah ialah jenis-jenis struktur dilihat dari gaya kalimat, cara pengungkapan, keringkasan, keluwesan ungkapan, dan keseimbangan ungkapan dengan maknanya. Ilmu yang seperti ini dibingkai dalam ilmu balaghah cabang ma'ani.

Kedua, aspek makna. Para sastrawan menelaah makna kata berdasarkan konvensi pemakaiannya yang melahirkan pembagian kata secara global ke dalam hakikat dan majaz. Ilmu ini terwadahi dalam ilmu balaghah cabang bayan. Ilmu bayan membahas kata dilihat dari tiga aspek makna: (1) makna konvensional, (2) makna tambahan, dan (3) makna kontekstual. Dalam linguistik modern, kajian seperti ini disebut leksikologi.

Ketiga, aspek keindahan ungkapan. Kajian ini dipayungi dengan ilmu balaghah cabang badi' yang memfokuskan perhatiannya pada unsur keindahan kata, kalimat, dan maknanya.

Tujuan utama membaca adalah memahami makna. Sedangkan Ujaran atau tulisan 
merupakan sarana untuk meraih tujuan itu. Untuk meraih makna itu. (Syihabuddin, 2002:29). Pembaca atau pendengar harus melakukan analisis struktur, leksikal dan kontekstual. Di sini analisis struktur dibagi dua, yaitu sintaksis dan morfologi.

Dalam analisis morfologi, pembaca perlu memahami tiga hal. Pertama, bahwa kata-kata itu memiliki sekumpulan makna morfologis, seperti nominal, verbal, ajektival, preposisional. Kedua, bahwa makna-makna morfologis tersebut disajikan melalui konstruksi yang beragam. Konstruksi ini terdiri atas kata dasar (mujarrad), kata yang telah mengalami afiksasi (mazid), dan kata dengan morfem zero. Ketiga, konstruksikonstruksi itu berhubungan satu sama lain, baik hubungan persesuaian maupun pertentangan.

\section{Stilistika al-Qur'an juz $\mathbf{3 0}$}

Setelah dilakukan identifikasi data stilistika dalam al-Qur'an Juz 'Amma, ditemukan bentukbentuk stilistika morfologis yang dapat diklasifikasikan sebagai berikut:

\section{Pertama, Penambahan satu huruf dalam wazan}

Ada 3 macam unsur stilistika morfologis yang terkait dengan penambahan satu huruf, yaitu:

\section{Penambahan harf illat}

Dalam al-Qur'an terdapat banyak unsur stilistik morfologis yang terkait dengan penambahan satu huruf, misalnya di surah Al-Nazi'at ayat 43 فيَمَ (أَنْتَ مِنْ ذِكْرَاهَا (أَوْ يَنَّكَرُ 4 dan di surah Abasa ayat

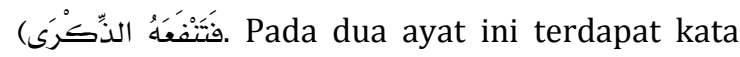
dzikra dengan tambahan harf illat dari kata asalnya dzikr, yaitu alif layyinah. Menurut Hanswer (tt:310) antara kata dzikr dan dzikra memiliki makna yang dekat, yaitu remembrance (mengingat), commemoration (peringatan). Demikian juga al-Ashfahani mengartikan keduanya dengan hifdz (mengingat) atau menjadikan sesuatu sebagai i'tibar (peringatan). Bila diamati, penggunaan kata dzikra lebih sering dipakai oleh al-Qur'an daripada ungkapan bahasa Arab non al-Qur'an. Di sinilah letak stililistika morfologis al-Qur'an.

\section{Penambahan tasydid}

Bentuk lain dari stilistika morfologis yang terkait dengan penambahan satu huruf, yaitu penambahan tasydid. Di surah al-Ghasyiayah ayat 16 tordapat tambahan huruf ya' yang ditasydid dan bukan termasuk $y a^{\prime}$ nisbah.
Penambahan tasydid pada kata zarabiyyu tidak diperlukan karena ia merupakan bentuk jamak dari zarbiyatun, sama halnya dengan kata kursiyyun bentuk jamaknya karasiy tanpa tasydid.

\section{Penambahan ha' saktah}

Al-Qur'an merupakan karya sastra tertinggi sehingga di dalamnya dijumpai banyak keserasian akhir (sajak). Karena itu, muncul penggunaan $h a^{\prime}$ saktah untuk menyelaraskan irama kalimat, sementara dalam ungkapan bahasa Arab non al-Qur'an jarang dijumpai hal tersebut. Contoh dari kasus ini terdapat di surah al-Qari'ah ayat 10 (وَمَا أَدْرَاكَ مَا هيَهَ). Asal dari kata maahiyah adalah maa hiya (apa itu?), tanpa ha' saktah.

\section{Kedua, Penghilangan Satu Huruf dalam Wazan}

Ada 5 macam unsur stilistika morfologis yang terkait dengan penghilangan satu huruf, yaitu:

\section{Penghilangan harf illat}

Ada dua contoh ayat yang di dalamnya terdapat penghilangan harf illat. Pertama, di surah Al-Fajr ayat 3 (وَاللَّيْل إذًا يَسنْرِ). Pada contoh ini dihilangkan huruf $y a^{\prime}$ pada kata yasri yang merupakan bentuk mudlari' dari kata saraa. Adapun alasannya, menurut al-Akhfasy, dihilangkannya ya' itu berfungsi untuk memalingkan makna bahwa malam itu tidak berjalan melainkan dijalankan. Kedua, di surah al-'Alaq ayat 18: (سنَنَُعُ الزَّبَانيَةً). Pada ayat ini dihilangkan huruf illat (wawu akhir) pada fiil mudlari' yang tidak dijazemkan.

\section{Penghilangan $t a^{\prime} t a f a^{\prime} a l a$}

Penghilangan satu huruf berikutnya yaitu $t a^{\prime}$ tafa'ala pada surah Abasa ayat 3 وَمَا يُدْرِيكَ لَعَلَّلَهُ

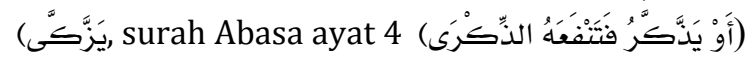

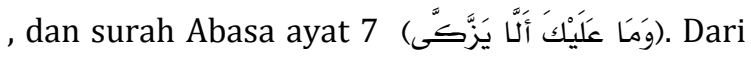
ketiga ayat ini ada kesamaan bentuk penghilangan $t a^{\prime}$ zaidah pada wazan tafa'ala. Dalam kaidah sharf tidak ditemukan wazan yaffa'ala melainkan yatafa'ala (Nashif, tt:6). Jadi, bentuk asal dari kata-kata di atas adalah yatazakkaa dan yatadzakkaru.

\section{Penghilangan $t a^{\prime}$ mudlaraah}

Selain penghilangan ta' tafa'ala, juga ada penghilangan $t a^{\prime}$ mudlaraah, sebagaimana

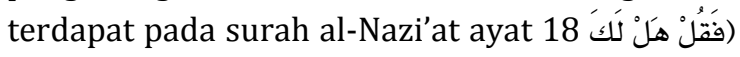

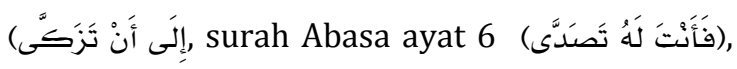

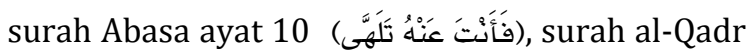




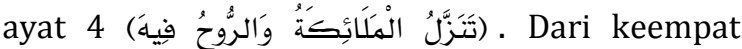
contoh tersebut terdapat huruf yang dihilangkan yaitu $t a^{\prime}$ mudlara'ah. Indikatornya adalah adanya 'an masdariyah dan dlamir anta yang mengharuskan untuk dijadikan mudlari' dengan $t a$ 'sebagai harf mudlara'ahnya.

Pada kata tanazzalu, belum terdapat ta' ta'nits untuk menyesuaikan dengan fail-nya (kata malaikah). Dalam konteks ini, ada dua alternatif yang harus dipilih, yaitu: tanazzalat (fiil madli) atau tatanazzalu (fiil mudlari'). Alhasil, jelas bahwa pada kata di atas, ta' mudlara'ah belum dimasukkan. Inilah yang merupakan bentuk kekhasan al-Qur'an.

\section{Penghilangan $y a^{\prime}$ mutakallim}

Apabila ya' mutakallim dilekatkan pada fill, maka ada kecenderungan untuk mengkasrahkan fiil dan ini patut dihindari. Untuk itu perlu dimasukkan nun pelindung terhadap kasrahnya fiil yang disebut dengan nun wiqayah. Meskipun demikian, justru dalam al-Qur'an yang dihilangkan adalah $y a^{\prime}$ mutakallim-nya, dan sebagai gantinya, nun wiqayah dikasrahkan. Contoh dari deskripsi ini adalah pada surah al-

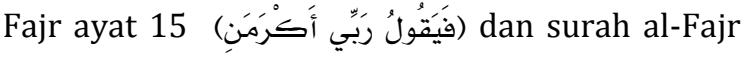
ayat 16 (فَيقُولُ رَبِّي أَهَانَنَ). Di kedua contoh ini terdapat nun wiqayah berharakat kasrah yang asalnya adalah akramanii dan ahananii.

\section{Penghilangan alif isim fail}

Unsur berikutnya yang menjadi kekhasan morfologi al-Qur'an, terkait dengan penghilangan, yaitu penghilangan alif isim fail. Isim fail untuk kata kerja yang terdiri dari tiga huruf asli (tsulasi mujarrad) memiliki rumus faailun. Khusus bagi fiil dengan huruf akhir ganda (mudla'af), bila ingin dibentuk menjadi isim fail, maka ia harus ditambah alif setelah $f a^{\prime}$ fiil dan tasydid dikembalikan menjadi dua huruf. Contoh, kata madda bila dibentuk isim fail, akan menjadi maadidun atau maaddun.

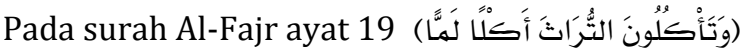
, kata lamma adalah masdar yang berarti mengumpulkan barang yang belum jelas halalnya (al-Qurtubi, 48/20). Namun, dalam kalimat tersebut kata lamman berposisi sebagai kata sifat yang mestinya menggunakan bentuk isim fail yaitu dengan menambah alif setelah lam, laamman. Demikian juga dengan surah Al-Fajr

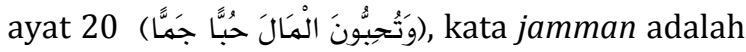
masdar yang berarti banyak atau menumpuk (alQurtubi, 49/20) namun dalam kalimat tersebut kata jamman berposisi sebagai kata sifat yang mestinya menggunakan bentuk isim fail yaitu dengan menambah alif setelah jim, shingga menjadi jaamman. Hal yang sama juga terjadi pada surah al-Nazi'at ayat 11 (أئذَا كُنَّا عِظَامًا نَخِرَةًا). Dalam bacaan Ibn Abbas dan Ibn Mas'ud kata nakhirah ditambah alif sehingga menjadi naakhirah (al-Qurtubi, 19/173. Jadi menurut kaidah nahwu, kata nakhirah harus dari isim sifat.

\section{Ketiga, Perubahan wazan}

Ada 5 macam unsur stilistika morfologis yang terkait dengan perubahan wazan, yaitu:

1. Perubahan wazan Jamak

Salah satu bentuk stilistika yang terkait dengan perubahan wazan, yaitu perubahan wazan jamak. Mengenai hal ini, ada 5 contoh yang terdapat alQur'an Juz 'Amma.

a. Surah al-Humazah ayat 9 (فِي عَمَنِ مُمَدَدَدةٍ ). Kata 'amad merupakan bentuk Jamak dari 'imad atau 'amud yang berarti tiang, belenggu neraka (al-Qurtubi, 173/20). Bentuk jamak semacam ini tidak ada dalam wazan katsrah maupun qillah. Yang sering dipakai dalam membuat jamak dari kata 'imad adalah a'midah.

b. Surah al-Naba' ayat 12 (وَبَيْنَا فَوْقَكُمْ سَبْعَا شِدَادَادًا). Menurut Hanswer jamak dari wazan fa'iil atau syadiid adalah syidaad atau asyiddaa', namun yang sering dipakai adalah yang terakhir, asyiddaa'.

c. Surah al-Naba' ayat 16 (وَجَنَّاتٍ أَلَفَفَاًا) . Penggunaan wazan af'aal untuk alfaaf merupakan bentuk jamak yang jarang dipakai dalam ungkapan non al-Qur'an, seakan ia bukan isim shifat bila dilihat dari bentuk wazannya. Namun, ada yang berpendapat bahwa kata tersebut sebagai jamak dari lafiif sebagaimana pendapat Abu Ubaidah (alQurtubi, 19/154).

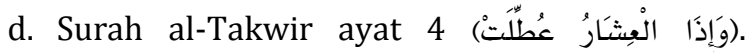
Menurut al-Qurtubi (19/198) kata i'syar adalah jamak dari kata asyra yang berarti unta bunting, padahal dari 15 kata tanggal (mufrad) yang jamaknya fi'al tidak ada yang berwazan asyra. Dari segi makna, ternyata tidak ada kaitan sedikitpun dengan 'asyarah (sepuluh).

e. Surah al-Buruj ayat 6 (إذْ هُمْ عَلَيْهَا قُعُدُد). Sepintas kata qu'uud tidak sesuai dengan bentuk mubtada'nya yang berbentuk isim dlamir 
jamak mudzakkar. Umumnya harus ada kesesuaian antara mubtada' dan khabar dalam hal jamak dan mudzakkarnya, padahal dalam kalimat tersebut, kata qu'uud berbentuk mufrad dan bukan isim shifat. Penggunaan masdar qu'uud semestinya menggunakan isim fail jamak qaa 'iduun.

\section{Perubahan wazan masdar}

Dalam Juz 'Amma banyak ditemukan perubahan wazan masdar, sebagaimana ayat-ayat di bawah ini.

a. نَاقَةَ اللَّهِ وَسُقِقيَاهَا (QS. al-Syams:13). Penggunaan wazan fu'laa yang mestinya masdar (saqyuha)

b. وَكَا يَخَافُ عُقِبَـاهَا (QS. al-Syams:15). Penggunaan wazan fu'laa yang mestinya masdar (aqibataha)

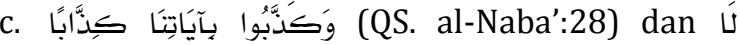

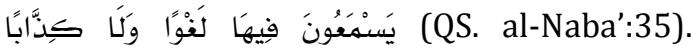
Penggunaan wazan masdarfi'aal yang mestinya taf'iil. Menurut al-Farra' kata kadzdzaab adalah bahasa Arab Yaman dan merupakan bentuk masdar dari kadzdzaba yukadzdzibu (al-Qurtubi, 19/159).

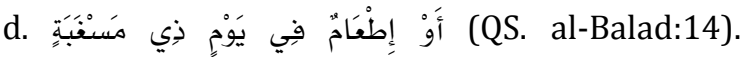
Penggunaan masdar mim yang mestinya menggunakan masdar ghairu mim (saghab) (Tafsir Qurtubi, 62/20).

e. يَتِيهًا ذَا مَقْرَبَةِ (QS. al-Balad:15) Penggunaan masdar mim yang mestinya menggunakan masdar ghairu mim (qarabah) (Tafsir Qurtubi, $62 / 20$ ).

f. أَوْ مِسْكِينًا ذَا مَتْرَبةٍة (QS. al-Balad:16) Penggunaan masdar mim yang mestinya menggunakan masdar ghairu mim (turab) (Tafsir Qurtubi, $62 / 20)$

g. وَتَوَاصَوْا بِالْمَرْحَمَةِ (Al-Balad 17). Penggunaan masdar mim yang mestinya menggunakan masdar ghairu mim (rahmah) (Tafsir Qurtubi, 64/20).

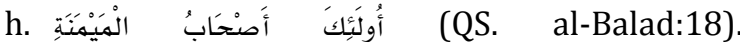
Penggunaan masdar mim yang mestinya menggunakan masdar ghairu mim yamin) (Tafsir Qurtubi, 64/20).

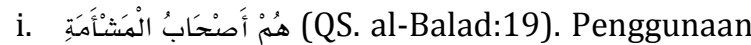
masdar mim yang mestinya menggunakan masdar ghairu mim (syu'm) (Tafsir Qurtubi, 65/20).

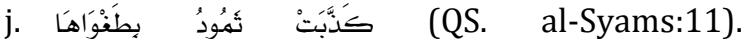
Penggunaan wazan thagwa sebagai masdar dari thagha yang mestinya tughyan.

k. إنَّ إلَى رَبِّكَ الرُجْجْىَى (QS. al-'Alaq:8). Penggunaan kata ruj'aa berfungsi sebagai masdar, mestinya menggunakan bentuk ruju' atau marji', namun menurut al-Qurtubi, kata ruj'a merupakan bagian dari masdar raja-a (20/114)

l. سكَامُ هِيَ حَتَّى مَظْلَع الْفَجْر (QS. al-Qadr:5). Menurut ali Kisai kata matla' itu isim zaman yang manyalahi qiyas (kaidah), semestinya waqta tulu'il fajr (Baidlawi, 514/1)

\section{Perubahan wazan isim shifat}

Isim shifat adalah isim yang dapat digunakan untuk mensifati kata. Isim shifat mencakup isim fail, isim maf'ul, shigat mubalaghah, dan sifat musyabbahah. Di bawah ini ditemukan bentuk shifat yang jarang ditemukan dalam ungkapan non al-Qur'an, yaitu:

a. إنَّ يَوْمَ الْفَصنْ كَانَ مِيقَانًا (QS. al-Naba':17). Penggunaan isim zaman yang semestinya isim maf'ul mawquuta atau sebagai bentuk lain dari kata waqtun.

b. جَزَاءٌ و وفَاقًا (QS. al-Naba':26). Penggunaan wazan fi'aal yang semestinya mafaa'il atau mawaqif (Al-Shabuny, tt: 3/509).

c. وَكَأَستًا دهََاقًا (QS. al-Naba':34). Penggunaan bentuk masdar di tempat yang semestinya isim sifat (yang bermakna penuh; مهتلئة).

d. فَكَكهينَ (QS. al-Muthaffifin:31) Penggunaan wazan isim sifat musyabbahah yang tidak lazim, yaitu fa'ilu.

e. إلَى رَبِّكَ كَدْحًا فَمَلَاقِيهِ (QS. al-Insyiqaq:6). Penggunaan wazan fa:'ala (mulaqah) yang lazimnya menggunakan wazan fa'ala; liqa' (AlQurtubi, 9/237).

f. إنََّهُ لَقَوْلُ فَصنْل (QS. al-Thariq:13). Penggunaan masdar sebagai kata sifat yang semestinya menggunakan isim sifat. 


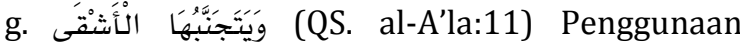
wazan af al (asyqa) pengganti isim fail syaqiy (Tafsir Qurtubi, 21/20).

h. يَقُولُ أَهْنَكْتُ مَالنًا لُبَدَا (QS. al-Balad:6). Penggunaan isim fail dengan wazan fuala yang berarti banyak atau menumpuk, asalnya adalah talabbada (Tafsir Baidlawi, 1/493).

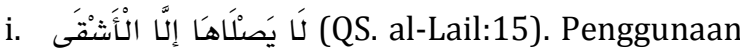
bentuk tafdil untuk kata yang semestinya isim sifat musyabbahah (syaqiyy) (Al-Shabuny, tt: $3 / 570)$

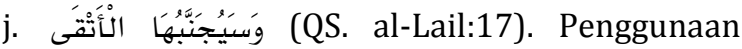
bentuk tafdiil untuk kata yang semestinya isim sifat musyabbahah (taqiyy).

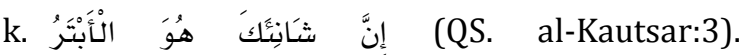
Penggunaan wazan isim tafdhil yang semestinya isim fail.

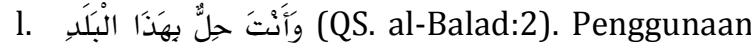
masdar untuk mengungkapkan pelaku yang mestinya menggunakan isim fail muhill.

\section{Perubahan jenis fiil}

Ditemukan pula perubahan jenis fiil yang menjadi kekhasan al-Qur'an, yaitu pada surah al-Insyiqaq

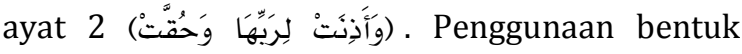
mabni majhul untuk kata kerja haqqa jarang terjadi karena ia bukan termasuk kata kerja transitif (muta'addi).

\section{Perubahan wazan isim}

Dalam surah al-Bayyinah ayat 6-7, terdapat dua kata sama yang berubah dari bentuknya semula,

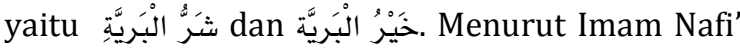
dalam tafsir al-Baidlawi, asal dari kata bariyyah adalah bariiah yang berarti watak atau sifat, jadi bukan $y a^{\prime}$ nisbah.

\section{Keempat, Perubahan makna}

Ada 3 macam unsur stilistika morfologis yang terkait dengan perubahan makna, yaitu:

\section{Perluasan makna isim}

Dalam al-Qur'an Juz 'Amma, banyak ditemukan perluasan makna, yaitu:

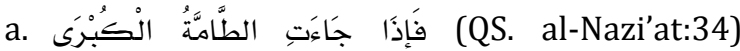
menurut Ibn Abbas dalam Mukhtashar Ibn Katsir 3/598, hari kiamat itu disebut juga dengan thammah karena ia merupakan bencana besar yang melebihi kedahsyatan bahaya apapun. Kata thamma asalnya berarti banjir.

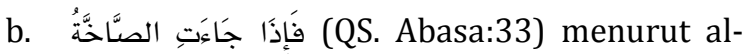
Shabuni, arti asal dari sakhkha adalah memekakkan telinga. Hari kiamat disebut juga shaakhkhah, karena dentumannya memekakkan telingan siapapun.

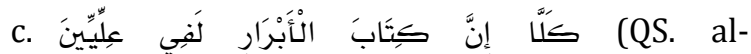
Muthaffifin:18) Penggunan bentuk jamak mudzakkar untuk ghairu 'aqil.

\section{Perluasan makna fiil}

Di samping ada perluasan makna pada isim, ditemukan juga perluasan makna pada fiil, yaitu pada surah al-Takwir ayat 18 (وَالصُُْح إِذا تَنَفَسن). Arti asal dari tanaffasa adalah bernafas, namun kata ini mengalami perluasan makna, menjadi "ketika waktu subuh sudah memancarkan cahayanya bagaikan deru nafas manusia .

\section{Perubahan makna}

Ada perbedaan sedikit antara perubahan makna dengan perluasan makna. Perluasan makna masih memiliki benang merah dengan kata asalnya. Sedangkan perubahan makna memiliki pengertian sebuah perubahan ekstrim yang memutuskan hubungannya dengan kata asal atau bahkan kontradiksi makna asalnya. Berikut ini contoh-contoh perubahan makna:

a. وَالسَّهَاء ذَات الرَّجْْ (QS. al-Thariq:11). Adapun makna raj'i di sini adalah hujan, sehingga bisa dikatakan bukan bentukan dari fill alias jamid.

b. يَقُولُونَ أَبَنَّنَا لَمَرْدُودُونَ فِي الْحَافِرَّة (QS. al-Nazi'at:10). Menurut sebuah pendapat kalimat tersebut termasuk isim fail dengan makna isim maf'ul yaitu mahfuurah (sesuatu yang digali/tanah).

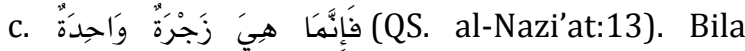
dilihat asal katanya zajara berarti larangan, namun dalam ayat tersebut berarti tiupan.

d. فَإِذا هُمْ بَالسَّاهِرَة (QS. al-Nazi'at:14). Pemaknaan kata sahirah yang tidak mencerminkan pelaku (isim fail) melainkan bermakna permukaan bumi.

e. بَأَيْي سَفرَة (QS. Abasa:15), kata safarah diartikan malaikat yang menjadi duta antara Allah dengan manusia utusannya. Kaitannya 
dengan kata safara yang berarti pergi, setiap duta pasti akan melakukan bepergian ke tempat yang diperintahkan.

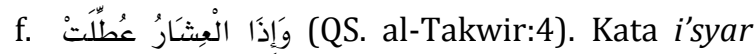
adalah jamak dari asyra yang berarti unta bunting, padahal dari 15 mufrad yang jamaknya fi'al tidak ada yang berwazan asyra. Dari segi makna ternyata tidak ada kaitan sedikitpun dengan 'asyarah (sepuluh).

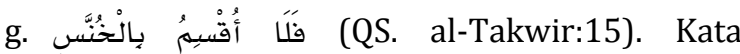
khunnas adalah bintang-bintang yang muncul di siang hari sehingga mata tidak mampu menangkapnya. Kata khanis arti asalnya menerobos masuk.

h. الْجَوَار الْكَنْسَ (QS. al-Takwir:16). Kata kunnas adalah kapal-kapal laut yang berjalan seiring matahari dan bulan, lalu bersembunyi di malam hari. Arti asal dari kunnas adalah lobang persembunyian biawak.

i. وَاللَّيْل إذذا عَسْعَسن (QS. al-Takwir:17). Kata as'as adalah kebalikan dari kata tanaffas, yakni ketika malam berselimutkan kegelapan.

j. كَفِي سِيجِيّن (QS. al-Muthaffifin:7). Kata sijjiin sangat dekat dengan sijnun yang berarti penjara. Dalam ayat tersebut diartikan sebagai lapisan tanah paling bawah yang sangat sempit.

k. وَمَزَاجُهُ مِنْ تَسنْيَ (QS. al-Muthaffifin:27) Penggunaan wazan yang mirip masdar tafiil, tetapi sebenarnya tidak berasal dari kata kerja dan berarti mata air surga.

l. وَاللَّهُ أَعَلْمُ بهَا يُوعُونَ (QS. al-Insyiqaq:23). Kata yu'uun berasal dari kata wi'a yang berarti wadah kecil dan bukan dari $w a^{\prime} a$ yang berati sadar, tapi berarti menutupi atau menjaga .

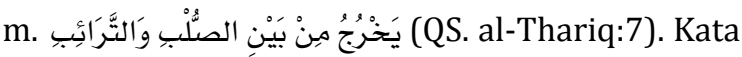
tara'ib adalah bentuk jamak dari taribah bukan dari turab, yang berarti tulung rusuk perempuan

n. وَالْأَرْضِ ذَات الصَّنَ (QS. al-Thariq:12). Kata shad'u berasal dari kata shada'a yang berarti pecah, tetapi yang dimaksud adalah tumbuhan.

o. وَالَنِْي أَخْرَجَ الْمَرْعَى (QS. al-A'la:4) Penggunaan isim makan (mar'a) dari kata ra'a yang berarti menggembala. Tetapi maksud dari ayat adalah rumput yang menguning

p. كَيْسَ لَهُمْ طَعَامُ إِلَّا مِنْ ضَرِيع (QS. al-Ghasyiyah:6) Kata dlari' bila dilihat dari bentuk katanya ia berwazan isim sifat musyabbahah (fa'iil)

q. وَكَا يُوثيقُ وَنَاقَهُ أَحَدِ (QS. al-Fajr:26). Kata yutsiq tersebut berasal dari autsaqa yang berarti mengikat, sedangkan watsaq bukan bentuk masdar tetapi isim jamid yang berarti tali .

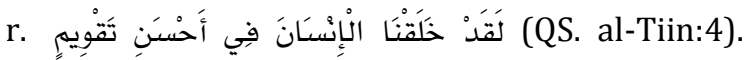
Penggunaan istilah taqwim yang diatikan bentuk, merupakan isim masdar dari qawwama yang berarti menilai atau meluruskan

s. أَلَمْ يَجْعَلْ كَيْدَهُمْ فِي تَضْلِيل (QS. al-Fiil:2). Penggunaan wazan taf'iil pada dlalla sangat langka, yang umum adalah dlalal.

t. وَأَرْنَلَ عَلَيْهُهْ طَيْرًا أَبَابيلَ (QS. al-Fiil 3). Kata ababil bukanlah nama burung, tetapi kata sifat yang berarti berbondong-bondong .

u. وَيَمنَعُونَ الْمَاعُونَ (QS. al-Maun 7). Kata ma'un berarti zakat dan ia termasuk jamid.

v. وَكَمْ يَكُنْ لَهُ كُفْوًا أَحَدْ (QS. al-Ikhlas 4). Kata kufuwan sangatlah dekat artinya dengan kufu'un, kufwun atau kuf'un, semuanya punya arti serupa, sebangun.

\section{Penutup}

Surah-surah pendek dalam al-Qur'an yang terdapat pada Juz 30 memiliki stilistika yang sangat menarik untuk diperhatikan dan dikaji sehingga dapat ditemukan bentuk-bentuk stilistika melalui telaah kitab-kitab tafsir. Lafadzlafadz pada juz ini tidak selalu mengikuti lafadzlafadz yang digunakan oleh penutur Arab sendiri. Ketika lafadz-lafadz itu dibacakan sebagai satu kesatuan dalam satu surah al-Qur'an, akan menimbulkan beberapa pengaruh yang antara lain keserasian sajak dan kesamaan huruf akhir tiap ayat yang hal ini makin menambah keindahan ayat-ayatnya jika diperdengarkan.

Adapun bentuk-bentuk stilistika morfologis pada juz 30 ini adalah penambahan satu huruf dalam wazan, penghilangan satu huruf dalam wazan, perubahan bentuk wazan, dan perubahan makna kata.Secara terperinci penambahan satu huruf ini mencakup penambahan harf illat, tasydid, dan ha' saktah. Untuk penghilangan satu huruf memuat 
penghilangan harf illat, ta' tafaala, ta' mudlara'ah, ya' mutakallim, dan alif isim fail.

Adapun yang terkait dengan perubahan wazan terdapat perubahan wazan jamak, masdar, isim shifat, jenis fiil, dan wazan isim. Untuk perubahan makna mencakup perluasan makna isim', makna fi'il dan perubahan makna.

\section{DAFTAR PUSTAKA}

Al-Shabuny, Muhammad Aly. Tanpa tahun. Shafwah al-Tafasir. Beirut: Dar al-Fikr.

Ayyad, Syukri Muhammad. 1982. Madkhal ila Ilm al-Uslub, Riyadh: Dar al-Ulum.

Keraf, Gorys. 1993. Komposisi. Flores: Penerbit Nusa Indah.

Kridalaksana, Harimurti. 1983. Kamus Linguistik. Jakarta: PT. Gramedia.

Lecce, Geoffrey. 1984. Style in Fiction. London: Longman.

Nashif, Hafni dkk. Tanpa tahun. Qawa'id al-Lughah al-Arabiyyah. Surabaya: Al-Hidayah.

Sudjiman, Panuti.1993. Bunga Rampai Stilistika. Jakarta: Pustaka Utama Grafiti.

Syihabuddin. 2002. Teori dan Praktik Penerjemahan Arab - Indonesia. Jakarta: Dirjen Dikti Diknas. 